\title{
Compensation Management and Motivation: Cooking utensils for Organisational Performance
}

\author{
Abayomi Olarewaju Adeoye \\ Department of Business Administration, Faculty of Management Sciences \\ Lagos State University, Ojo, Lagos, Nigeria \\ eveyom@yahoo.com \\ Ayobami Folarin Elegunde \\ Department of Business Administration, Faculty of Management Sciences \\ Lagos State University, Ojo, Lagos, Nigeria \\ emolomo2003@yahoo.com
}

Doi:10.5901/mjss.2014.v5n27p88

Abstract

The achievement of organisational performance is essential for sustainability and continuous existence of the organisation. Obviously, this is a function of employees that are well remunerated and motivated, thus, it is contingent that compensation management and employees motivation should be aligned with the vision, mission and objectives of the organisation. In doing this, the attainment of organisational performance becomes an easy task and it will also reduce the antecedent negative impact of absenteeism, labour turnover, industrial unrest and non-commitment attitude of the employees. Efficient and adequate compensation management and employees motivation will improve organisational productivity and image of the organisation. In order to attract, hire and retain skilful employees that will ensure the achievement of organisational performance, it is therefore; recommended that there should be a periodical review of compensation package. It is against the backdrop of the import of compensation and motivation as cooking utensils for organisational performance that this addressed.

Keywords: Compensation management, Employees, Motivation, Organisation, Performance

\section{Introduction}

In the global world of today, for any organisation to have competitive edge amidst her competitors, there must be in place a formidable compensation strategy to attract, motivate people to join the firm. This should also reduce the turnover intent from the employees.

The need for organizations to develop a programme that will facilitate a performance-enhancing system leading to the best management and development of employees and thus increase their competitive advantage has made the links between human resource management and organisational performance a prominent issue in the field of human resource management across the core functional areas of human resource practices. These practices range from staffing, performance appraisals, training and development, manpower planning, workers management participation and compensation management. Notably, the relationship between compensation management and performance has been visible in the management literature. It is generally believed that if there is proper management of compensation, individuals can be motivated to perform and thus have a resultant positive effect on the organisational performance (Tsai, 2005)

Compensation management is a global phenomenon that determines the hiring and retention of employees to attain the objectives of an organisation as well as that of an individual employee which is also used as a means of control and is the basis of involvement of individuals (Greckhamer, 2011; Xavier, 2014). Cox, Brown and Reilly (2010) found that the North American reward strategy has greatly influenced the reward system in many parts of Europe especially UK. Nigeria being part of the global world, compensation management also plays a vital role in motivating employees to work harder in order to accomplish the set goals of the organisation (Idemobi et al., 2011; Odunlade, 2012)

Motivations as a phenomenon in human resource management and contemporary management have been widely research into (Kelly, 2009; Ahlstrom \& Bruton, 2010; Seiler et al, 2011). Motivation is that propeller that energises behaviour, gives attitudinal direction and underlies the continuous persistence even when an individual employee faces 
one or more challenges (Grobler et al., 2011; Mathis and Jackson, 2011; Brevis and Vrba, 2014).

\section{Compensation Management}

Various definitions have been given on compensation. Literally, compensation is a form of reward given as a result of a job that has been done or effort put in to achieve a set goal and as such this serves as a motivational factor that encourages an individual to put more energy or commitment into his or her job (Armache, 2012; Ederer and Manso, 2013; Qureshi, 2013). In most organisations, the main aim of compensation is to motivate the behaviour of the employee in a particular way. Hence, an organisation not only desires to motivate employees to stay within the organisation, but reinforces employee's performance through adequate and encouraging compensation. The three major elements in motivation have been stated as that: which is important to a person, offering it as an exchange, and the desired behaviour (Milkovich \& Newman, 1999, Riddell, 2011, Shaw, 2014).

Hills et al., (1994: 11) on one hand define compensation 'as the total sum of wage or salary, employee benefits, non-recurring financial rewards and non-pecuniary rewards'. While Milkovich et al., (2011: 10) on the other hand define compensation as 'all forms of financial returns on tangible services and benefits employees receive as part of an employment relationship'.

Martocchio (2004: 2) argues that 'compensation represents both the intrinsic and extrinsic rewards employees receive for performing their jobs. Intrinsic compensation reflects employees psychological mind sets that result from performing their jobs whilst extrinsic compensation includes both monetary and non-monetary rewards'.

Worldatwork (2007: 7) is of the view that compensation is a 'pay provided by an employer to an employee for services rendered (that is, time, effort, and skill). It includes both fixed and variable pay tied to levels of performance' whereas Carrell (1998: 370) states that 'compensation is what employees receive in exchange for their contribution to the organisation'. It is notable therefore that 'compensation is tied to performance'.

Compensation or reward management aims at the formulation and implementation of strategies and policies that are aimed at rewarding people fairly, equitably and consistently in accordance with their value to the organisation (Brauns, 2013; Karami, Dolatabadi \& Rajaeepour, 2013; Pingle, 2014). It deals with the design, implementation and maintenance of reward practices that are geared towards the improvement of organisational, team, and individual performance (Dauda, 2010; Abolade, 2012). Compensation management is an integral part of an human resource management approach to managing people, and as such it supports the achievement of the business strategy and is concerned with developing a positive employment relationship and psychological contract, to address longer term issues relating to how people should be valued for what they do and what they achieve (Sisson, 2010; Musenze, Thomas, Stella \& Muhammadi, 2013). It embraces both financial and non-financial rewards, and thus all these need to be taken into account and integrated in order to maximise the effectiveness of reward policies and practices (Armstrong, 2003). Compensation management connotes putting in place a fair compensation structure where employees are rewarded for their efforts (Hewitt, 2009). This serves as a source of encouragement to top and great performers to put in more effort and work harder so that jointly they may help in building a robust and highly competitive atmosphere in the organisation (Hewitt, 2009).

\subsection{Characteristics of compensation}

Muchinsky et al., (1998: 227) list the major characteristics of compensation as follows:

- It enhances improvement of both individual and organisational performance.

- It encourages value-added performance.

- It gives room for flexibility by helping to achieve the most efficient wage of human resources within the organisation.

- It provides managers with a support base.

- It facilitates organisational strategic objectives.

- It motivates employees.

- It makes the labour market more competitive by attracting and retaining highly skilled and quality people.

- It gives room for fair play and equity.

- It offers value for money.

- It encourages teamwork (Martocchio, 2006: 18-23)

Milkovich et al., (2011: 15-18) highlight certain objectives of compensation as follows: 
- It creates room for efficiency in terms of improving performance, increasing quality, delighting customers and stockholders:-

- Controlling labour costs.

- Compliance.

- Ethics (Grobler et al., 2011; Mathis \& Jackson, 2011).

\subsection{Types of compensation}

There are various forms of compensation and nearly all these forms of compensation can be categorised into four broad types (Muchinsky et al; 1998: 226). The four broad types are:

Wages and Salary: Wages are what is paid to employees who are not permanently employed and typically pertains to hourly rates of pay (the more hours worked, the greater the pay), while salary is what is paid to people that are permanently employed and this is at a fixed weekly, monthly, or annual rate of pay.

Incentive Plans: This is an additional compensation which is above and beyond the employees wage or salary provided. It may be long term or short term in nature.

Employee Benefit Programmes: Time off with pay, pension scheme, tuition reimbursement, recreation activities, cafeteria services are all examples of employee benefit programmes.

Additional Privileges: Employees in organisations may have other privileges such as the usage of company vehicles/cars, club membership or travelling allowance. These privileges may be a substantial part of compensation, especially for the executives.

\subsection{Objectives of compensation management}

The main objectives of the compensation function are to create a system of rewards that is equitable and acceptable to both parties in employment relationship. The resultant outcome of compensation is an employee who is attracted to the work and motivated to do a good job for the employer. Ivancevich (2004: 298) and Nickels et al (1999: 331) highlight the objectives of compensation as follows:

Attract: Attracting the right kind of people in terms of qualification and experience as required by the organization and in sufficient numbers.

Equitable: Each person should be treated fairly as regards the amount paid in line with his or her effort, abilities, skills and training acquired.

Balanced: Pay, benefits and other rewards should provide a reasonable total reward package.

Security: Providing employees with some sense of financial security through insurance and retirement scheme.

Cost Effective: The pay should not be excessive, considering what the organization can afford to pay.

Incentive-Providing: The pay should provide incentives that will motivate effectively, efficiently and productively at work.

Retention: The pay should be able to keep valued employees from leaving and going to competitors or starting competing firms.

Competitive Position: The pay should maintain a competitive advantage in the market place by keeping costs low through high productivity from a satisfied workforce.

\section{Motivation}

The word motivation means different things to different people and it was coined out of a Latin word "movere" which means to move or change a thing (Adeoye, 2001). Mathauer and Imhoff (2006: 3) define motivation as "the willingness to exert and maintain an effort towards organisational goals". Adeoye (2001: 46) argues that "motivation is an inducement to arouse the interest of an employee to achieve a set up goal of an organisation". Alstrom \& Bruton (2010: 200) are of the view that motivation is "the driving force behind an individual's actions that energizes and directs goal-oriented behaviour".

Malik (2010) assert that motivation is always viewed as making somebody to take action to execute something with the prompt that he/she wants to do it. The assumption before was that motivation has to be from outside but the perception now is that motivation arises because of several different forces or reasons. According to Malik (2010) motivation is an assignment that must be undertaken by managers to get the best result from their subordinates. This 
covers possession of communication skill, leading by example, which is like mentoring the junior ones, in facing difficult challenges. It is also to serve as an encouragement, giving necessary feedback, and to be involved, delegate, educate, train and develop the subordinate, towards being properly informed, and to brief and provide adequate and just remuneration. Malik (2010) concluded by defining motivation "as an inner force that drives individuals to accomplish personal and organisational goals". It is further argued by Malik (2010), Abdullah and Islam (2012) and Cong, Van and Huu (2013) that individuals have problems enunciating in a consistent manner what they are particularly good at in a job. Hence, most employers of labour have conscientiously ignored what the individuals are saying as regard what they want. Rather they tell the employees' what they are expecting from them, based on what the managers understand about the worker's need at any particular period or circumstance. Most often, the employer's decisions have been anchored on Maslow's hierarchical needs including the factor of proficiency (Islam \& Ahmed, 2014). As a person grows with an organisation, his employer makes available opportunities to meet the higher needs on Maslow's pyramid. Maslow's findings suggest that one of the key factors that motivate employees to higher productivity includes living in a safe area as well as receiving good pay (O'Connor \& Yballe, 2007). Maslow also makes some recommendations to the effect that reward structures should include job enlargement, job enrichment, promotions, monetary, and non-monetary compensation (Brevis \& Vrba, 2014).

Kulkarni (2011) argues that motivating an employee is always a challenge to the employer of labour. It is argued knowing the level of dedication and commitment of an employee to the organisation, division or team, depends largely on the individual involved. However, the relationship between motivation and job or organisational performance and job satisfaction cannot be underestimated. Kulkarni (2011) asserts that motivation is an attempt to operate organisational conditions, which gingers the employee's emotion into an action that makes him or her work toward the attainment of organisational goals. The main objective of motivation is to fashion out conditions upon which people have the willingness and conviction to work with zeal, initiative, interest and eagerness to work without being monitored or supervised (Hewitt, 2009; Wininger \& Norman, 2010). In this regard, motivation is geared towards achieving group morale, satisfaction with a sense of responsibility, loyalty, discipline, and pride with total confidence in such a consistent manner so that the goals of the organisation or firm are realisable in an efficient and effective way (Bob, 2011). In the study titled "revisiting Maslow the "IT" way-a case study". Kulkarni (2011) reveals that the safety and social needs, which are part of the need levels identified by Maslow, are more important to the employees of the IT industry in India than the esteem and selfactualisation needs. This was corroborated by the work of Mawoli and Babandako (2011) that the academic staffs of Ibrahim Badamasi Babangida University, Lapai, Niger State in Nigeria are highly motivated and contented with the working environment, which is about the safety nature of their job.

Živković (2013), in his work on management of occupational safety by motivating employees to work safely, while quoting from Mawoli and Babandako (2011) defines "motivation as a psychological process that causes the arousal, direction, intensity and persistence of behaviour. The potency of motivation in the physical working environment has great value in the performance of employees (Iguisi, 2009, Živković, 2013). In motivating for occupational safety, it is of great necessity for the employees to use safety measures in their position, and those measures must be current, sufficient and adequate to avert danger and harm (Živković, 2010). Furthermore, one of the essential factors for applying occupational safety measures as workers' motivation for this particular area is to reduce occupational accident, which is the motivation for constant respect of the rights and responsibilities they have in the area of safety (Todorović \& Živković, 2010). Employees' motivation is just a segment in human resource management development strategy (Ukandu \& Ukpere, 2011).

\subsection{Types of motivation}

Financial motivation: Financial motivation is said to be direct or indirect. Direct financial motivation comprises the pay an employee receives in the form of wages, salaries, bonuses or commissions while indirect financial motivation consists of all financial motivation or rewards that are not included in direct financial motivation such as vacation, child care or elder care, and various kinds of insurance (Invancevich, 2004: 298).

Non-Financial motivation: Non-financial motivation is a kind of motivation that does not involve monetary terms like praise, responsibility, self-esteem and recognition which affects the motivation and productivity of an employee (Ivancevich, 2004: 298). It is not enough to motivate workers with money alone but could be combined with non-monetary incentives such as recognition to enhance greater productivity (Willis-Shattuck, Bidwell, Thomas, Wyness, Blaauw and Ditlopo, 2008; Mattson, Torbiöm \& Hellgren, 2014). Similarly, Chandler, Chonya, Mtei, Reyburn and Whitty (2009) opine that social status expectations, working environments and relationships between different cadres at workplace as nonfinancial motivators goes a long way to ginger workers toward higher performance. 
Intrinsic motivation: This simply means doing an activity for the sake of doing that activity which denotes that the activity is interesting, engaging and brings satisfaction. For instance, the acceptability of internet-based learning medium by students is basically based on perceived enjoyment for their intention to use the new learning medium (Lee, Cheung and Chen, 2005). This could also be engaged in the Nigerian insurance industry to boost the performance of their employees by sending them on computer training. In the same vein, intrinsic motivation could be derived through knowledge sharing. Employees get fulfilled by enhancing their knowledge self-efficacy or assurance in their effort by providing useful knowledge to the firm to broaden the performance of the firm as well as their own performance (Lin, 2007; Cruz, Pérez and Cantero, 2009).

Extrinsic motivation: Extrinsic motivation is a means to satisfy indirect needs or something given by someone else as recognition for good work done, for example, pay increases, praise and promotion. These are motivation that is anchored on the achievement of a desired goal or some other kind of external remuneration such as money or awards (Walker, Greene and Mansell, 2006). Lin (2007) was of the opinion that extrinsic motivation centers on the goal-driven reasons such as recompenses or remunerations gotten when executing a duty. He submitted that the combination of both intrinsic and extrinsic motivation affects individual intentions concerning an activity as well as their real attitude. This view was supported by the study done by Kim, Shim and Ahn (2011) that extrinsic motivation deals with behaviours that are engaged in response to activities that is apart from its own sake, such as payments or recognition or the dictates of other people. This is relevant to this study in the sense that without team work, the expected performance may not be achieved.

\subsection{What motivates or energies employees}

Notably, human resources is the greatest asset that any organisation can have to achieve the goals and objectives of the organisation as well as enjoying competitive advantage in the industry in which the organisation is operating. To accomplish this, there is a need for motivation, hence, 'managers must motivate employees and understand how to get the best from the employees every-day of the week. Motivation is the world's greatest management principle, it is in light of this that understanding what motivates the employees, getting creative with rewards, and recognition as well as putting together a system of low-cost rewards is crucial (Nelson \& Economy, 2005: 59).

Nelson and Economy (2005: 62-66) argue that managers should not believe that the only thing that their employees want is money but suggest that managers can develop and maintain motivated, energised employees with little or no cost. This according to Nelson and Economy (2005) is a function of how employees are treated on a daily basis. They argue that manager can do the following to energise the employees.

Praise: This is a form of saying thank you to the employees by their manager not verbally alone but through writing e-mail, and short message services (sms). It is contended that taking time to say you recognise them, makes the employees to do more than they would normally do (Corpus \& Lepper, 2007; Grant \& Gino, 2010; Mumm \& Mutlu, 2011).

Support and involvement: Managers should support their employees by providing them with needed information regarding their job and allow them to be involved in decision-making processes, by seeking their opinion and ideas in respect of the job they do and equally support them when they make mistakes in the course of carrying out their daily or routine duties (Marinak \& Gambrell, 2008; Prebensen, Woo, Chen \& Uysal, 2012).

Autonomy and authority: In most cases, employees are of the view that they should be allowed to do their job in the best way they could, that is, making them to do their duties independently and allow them to have authority over the job by giving them a choice of assignment whenever it is possible. They should be given opportunities of having autonomy and authority to get their job done and the ability to spend or allocate resources, thus making decisions and manage others (João, Calheiros \& Barata, 2012; Cooman, Stynen, Van den Broeck, Sels \& De Witte, 2013).

Flexible working hours: Time is a precious thing to the employees and it is the new money for today's employees who expect work to be integrated into their life and not consume their entire lives. It is employee desire to have more time with their families; managers should be sensitive to the free time of their employees irrespective of how it is being spent, for example, with their families, church activities, leisure and so on. Thus, managers should be more flexible in using time (McNall, Masuda \& Nicklin, 2010; Van den Broeck, De Witte, Vansteenkiste, Germeys \& Schaufeli, 2011).

Learning and development: Employees cherish the opportunities in which they can acquire new knowledge and skills that broaden their horizon regarding the job and that enhances their worth and marketability in their current job as well as future positions. Thus, managers should support employees to learn new ideas, skills and acquire more knowledge relating to their job by discussing career options with them (Egan, Yang \& Bartlett, 2004; Tabassi \& Abu Bakar, 2009; De Rljdt, Stes, van der Vleuten \& Dochy, 2013; Hung, Lai \& Chang, 2011).

Manager availability and time: It is recommended that managers spend more time with their employees out of 
their busy schedule as this adds value to the employees and inspire them to do more. This then serves as a practical purpose of learning and communication, answering questions, discussing possibilities, or just listening to an employee's ideas, concerns and opinions (Collings \& Mellahi, 2009; Jacobsen, Hvitved \& Andersen, 2013).

Malik (2010) argues that there are other factors that are neither financial nor monetary in nature that motivate employees to do their best in terms of achieving the set goals of the organisation. These motivational factors are rated according to the level of their importance to the employees of the university where the research was conducted. These motivational factors are living in a safe area, good salary, promotion and growth within the organisation, interesting work, conducive working condition cum environment, sympathetic help with personal problems, appreciation of work done and finally, personal loyalty to employees which is also known as organisational commitment (Abdullah \& Islam, 2012; Fagley \& Alder, 2012).

Gupta and Tayal (2013) through their empirical work on the impact of competing forces of motivational factors at work place established that the desire for position, power, and security were highly ranked factors that motivate male workers' to produce more. On the other hand, for the female sets, the need for security, achievement, working conditions and appreciated by management were the motivating factors for them.

\subsection{Characteristics of motivation}

For motivation to be effective and accomplish the main aim of it in an organisation, it is therefore imperative that it must possess some characteristics and these characteristics includes the following: -

Enhancing high productivity performance: motivation is put in place to increase the level of productivity within the organisation so that the competitive advantage of the firm is realisable within a short frame of time.

Boosting the morale of the employees: motivation is also provided for within the firm to serve as an encouragement to the employees so that they would do their best by being devoted, dedicated and committed to the set-up goals of the organisation.

Enhancing career development among employees: motivation is set up to serve as an enhancement to the career development of employees and this becomes achievable through the organised programmes that are being sponsored by the organisation in the form of training like on-the-job training, off-the-job training, just-in-time and train the trainers technique. The development programmes are an enhancement to career development for those employees in the executive cadre by sending them to conferences, seminars, simulation, brain storming, and role playing development programmes.

Enhancing self-determination through employee contribution to teamwork within the organisation: motivation is equally structured for each employee to determine for himself or herself what he or she is going to contribute in the section where they work or serve within the organisation and this is done through team spirit or what is referred to in management as "enspirit de corps".

Integrating the organisations strategy with the organisation's mission, vision and objectives: the integration of the mission, vision, and objectives alongside with the organisation's strategy goes a long way in motivating the employees because they have an understanding of what the organisation's strategy is all about, what the vision, mission and objectives are all about and also in terms of being a leader in the industry, working towards customer satisfaction, protecting the interest of the shareholders as well as those of the employees.

\section{Organisation}

Organisation as a word describes the identity of a group or firm. Organisation could be an age group within a community, civil society, unions or a business entity. Daft (2007: 10) define organisations "as social entities that are goal-directed, designed as deliberately structured and coordinated activity systems and are linked to the external environment."

Robbins (2005: 4-5) argues that "organisation is a consciously coordinated social unit composed of two or more people, and that functions on a relatively continuous basis to achieve a common goal or set of goals".

Schermerhorn, Hunt \& Osborn, (2008: 8), Robbins and DeCenzo (2008: 4) assert that an organisation is the arrangement of people in organised form for achieving a desired goal. It could be concluded that organisations are established for the achievement of a certain goal by using people and such organisations include manufacturing and service industries, social clubs, schools, hospitals, military units, to mention but a few. 


\subsection{Organisational performance}

Organisational performance is a paramount thing to the business owners either it is a manufacturing or service rendering organisations as in the case of this study dealing with insurance services. The necessity of getting to know the wellbeing of an organisation in terms of performance is evident today in the global markets. This is done to attract future investment, increase the share value and attract high calibre employees within the competitive environment (Kagioglou et al. 2001: 86; Katou \& Budhwar, 2006). Traditionally, OP has been looked into through the financial indicators alone and these are the subject of interest to the owners of the business and such include return on investment (ROI), earnings per share (EPS), earnings before tax (EBIT), sales or revenue, profit. Kohlbacher and Gruenwald (2011) carried out an empirical study on firm performance in Austrian Corporations operating in the metal and machinery industry by interviewing 152 organisations. They use two constructs namely process performance measurement and the process owner role. They found that improvement on firm performance can be achieved through both concepts.

Similarly, Vukšić, Bach and Popovič (2013) opined that firm performance can be strengthened through business process management and business intelligence systems. They concluded that there is no strong commitment to adopt both systems to accomplish greater performance management. In the Nigerian context, this has been lacking. In the private sector, which is the focus of this study, business owners are only interested in how much that comes in and not minding how the firm performs (Odusami, lyagba and Omirin, 2003; Ehikioya, 2009). This has been the bane of most private businesses in Nigeria. Firm performance is an issue that emerges from the layout and execution of the human resource management policy for an organisation. The essence of an investment by any firm is to improve skills, knowledge and employees capacity with an expectation that the employees will increase productivity in the future (Shieh, 2008; Huang \& Lien, 2012).

\subsection{Relationship between compensation management, motivation and organisational performance}

There is congruence between compensation management, motivation and organisational performance that are the three major construct of this study. This is to say that the three variables are highly related. Stringer, Didham and Theivananthampillai (2011) in their study about motivation, pay satisfaction and job satisfaction at the retailer that uses a pay-for-performance plan for front-line employees in Australasia found that motivation is positively related to pay satisfaction which in turn enhances the outcome of the organisation. It was further stressed that the qualitative insights shows a degree of importance of pay fairness through the comparisons made with others by the respondents. The respondents shared the belief that what they are receiving does not compliment their effort.

Similarly, Ghazanfar, Chuanmin, Khan and Bashir (2011) found through their study conducted on managerial cadre employees of the sales departments of the cellular service providers in Lahore, Pakistan that there is a strong rapport between compensation and work motivation that leads to satisfaction on the job which in turn has a bear on the performance of the organisation. Likewise, there is strong linkage that exists between compensation management and motivation of employees. This was asserted by Khan and Mufti (2012) through their research on effect of compensation on motivating employees in public and private banks of Peshawar (Bank of Khyber Ltd and United Bank Limited). It was revealed that employees are not motivated because of their skills nor when they are informed that they would be rewarded rather they are motivated if the reward is on something they value. This also is having a significant impact on organisational performance.

Armache (2012) studied the effect of compensation and other motivational techniques on organisational productivity and found that there is a corollary effect on organisational performance when employees are well compensated and highly motivated. Ude and Coker (2012) found that incentive schemes impacts highly on employees motivation and productivity in both the organised private sector and public sector organisations in Nigeria.

\section{Conclusion and Recommendation}

Compensation management and motivation has been observed by scholars and enunciated to be very fundamental to an organisation and in enhancing its performance. For an organisation to stand a test of time and to enjoy competitive advantage in a competing environment, effective compensation strategy and for motivational factors must be put in place to attract, retain and develop skilful employees that will be dedicated, committed and endeared to the achievement of the organisational set goals. Compensation management and motivation as a veritable instrument in the hand of managers can be adopted to reduce absenteeism, labour turnover, industrial unrest and so on within the organisation thus improvement on organisational performance and employees performance is guaranteed that lead to competitive 
advantage.

However, for any organisation to enjoy sustainability and remain on top, adequate remuneration and motivational process must be entrenched to the philosophy of the organisation that will be of great interest to both the employees and the organisation. This can be achieved through periodical review of the remuneration package by the organisation.

\section{References}

Abolade, D.A. (2012). Impact of unionisation and non-unionisation of workers on organisational efficiency in work organisations in southwestern Nigeria. Economic Insight-Trends and Challenges, 64(2), 19-29.

Abdullah, A.M.B. \& Islam, R. (2012). Employee motivational factors: A comparison between Malaysia and Sultanate of Oman. Journal of Global Business Advancement, 5(4), 285-306.

Adeoye, A.O. (2001). Contemporary issues in human resources management and organisational behaviour. Lagos, Nigeria: Pumark Publishers.

Ahlstrom, D. \& Bruton, G.D. (2010). International Management: Strategy and Culture in the Emerging World, London: South-Western, Cengage Learning, EMEA.

Armache, J. (2012). Effect of compensation and other motivational techniques on organisational performance. Franklin Business and Law Journal, March (1), 88-96.

Armstrong, M. (2003). A handbook of human resource management practice. 9th Ed., Great Britain: Cambrian Printers Ltd., Aberystwyth, Wales.

Bob, N. (2011). Making employees suggestions count. Journal of Personnel Management, 17, 20-41.

Brauns, M. (2013). Aligning strategic human resources management to human resources, performance and reward. International Business and Economic Research Journal, 12(11), 1405-1410.

Brevis, T. \& Vrba, M. (2014). Contemporary management principles. South Africa: Juta and Company Ltd.

Carrell, M.R. (1998). Human resource management in South Africa. South Africa: Prentice Hall.

Chandler, C.I.R., Chonya, S., Mtei, F., Reyburn, H., \& Whitty, C.J.M. (2009). Motivation, money and respect: A mixed -method study of Tanzanian non-physician clinicians. Social Science and Medicine, 68(11), 2078-2088. http://dx.doi.org/10.1016/ j.socscimed.2009.03.007

Collings, D.G. \& Mellahi, K. (2009). Strategic talent management: A review and research agenda. Human Resource Management Review, 19(4), 304-313.

Cong, N.N., Van, D.N., \& Huu, T.H. (2013). Effects of motivation on employees' performance at Petrovietnam Nghe An Construction Joint Stock Corporation. American Journal of Business and Management, 2(2), 160-164.

Cooman, R.D., Stynen, D., Van den Broeck, A., Sels, L., \& De Wittle, H. (2013). How job characteristics relate to need satisfaction and autonomous motivation: Implications for work effort. Journal of Applied Psychology, 43(6), 1342-1352.

Corpus, J.H. \& Lepper, M.R. (2007). The effects of person versus performance praise on children's motivation: Gender and age as moderating factors. Educational Psychology, 27(4), 487-508.

Cox, A., Brown, D., \& Reilly, P. (2010). Reward strategy: Time for a more realistic reconceptualisation and reinterpretation. Thunderbird International Business Review, 52(3), 249-260.

Cruz, N.M., Pérez, V.M., \& Cantero, C.T. (2009). The influence of employee motivation on knowledge transfer. Journal of Knowledge Management, 13(6), 478-490.

Daft, R.L. (2007). Understanding the Theory and Design of Organisations, International Student Ed., USA: Thomson, South-Western.

Dauda, Y.A. (2010). Technological innovation and organisational performance: Employee relations strategies. Nigerian Journal of Industrial Relations, (NIRA) 11, 96-110.

De Rljdt, C., Stes, A., Van der Vleuten, C., \& Dochy, F. (2013). Influencing variables and moderators of transfer of learning to the workplace within the area of staff development in high education: research review. Educational Research Review, 8, 48-74.

Ederer, F. \& Manso, G. (2013). Is pay for performance detrimental to innovation? Management Science, 59(7), 1496-1513.

Egan, M.; Yang, B., \& Bartlett, K.R. (2004). The effects of organisational learning culture and job satisfaction on motivation to transfer learning and turnover intention. Human Resource Development Quarterly, 15(3), 279-30.

Ehikioya, B.I. (2009). Corporate governance structure and firm performance in developing

economies: Evidence from Nigeria. Corporate Governance, 9(3), 231-243.

Fagley, N.S. \& Alder, M.G. (2012). Appreciation: A spiritual path to finding value and meaning in the workplace. Journal of Management, Spirituality and Religion, 9(2), 167-187.

Ghazanfar, F., Chuanmin, S., Khan, M.M., \& Bashir, M. (2011). A study of relationship between satisfaction with compensation and work motivation. International Journal of Business and Social Sciences, 2(1), 120-131.

Grant, A.M. \& Gino, F. (2010). A little thanks goes a long way: Explaining why gratitude expressions motivate prosocial behaviour. Journal of Personality and Social Psychology, 98(6), 946-955.

Greckhamer, T. (2011). Cross-cultural differences in compensation level and inequality across occupations: A set-theoretical analysis. Organisation Studies, 32(1), 85-115.

Grobler, P.A., Wärnich, S., Carrell, M.R., Elbert, N.F., \& Hatfield, R.D. (2011). Human resource management in South Africa. $4^{\text {th }}$ ed., UK: Cengage Learning EMEA.

Gupta, A, \& Tayal, T. (2013). Impact of competing force of motivational factors on employees at work place. Information and Knowledge Management, 3(5), 143-148. 
Hewitt, A. (2009). Managing performance with incentive pay. Journal of Personnel Management, 7(1), 20-31.

Hills, P.S.; Bergmann, T.J., \& Scarpello, V.G. (1994). Compensation decision making, $2^{\text {nd }}$ Ed., New York: The Dryden Press.

Hung, S.Y., Lai, H.M., \& Chang, W.W. (2011). Knowledge-sharing motivations affecting R\&D employees' acceptance of electronic knowledge repository. Behaviour and Informantion Technology, 30(2), 213-230.

Huang, C.F. \& Lien, H.C. (2012). An empirical analysis of the influences of corporate social responsibility on organisational performance of Taiwan's construction industry: Using corporate image as a mediator. Construction Management and Economics, 30, $263-275$.

Idemobi, E. I., Onyeizugbe, C. U., \& Akpunonu, E. O. (2011). Compensation management as tool for improving organisational performance in the Public Sectors: A study of the Civil Service of Anambra State of Nigeria. Sacha Journal of Policy and Strategic Studies 1(1), 109-120.

Iguisi, O. (2009). The cultural dynamics of management leadership in Africa: Management in Nigeria, 44(2), 6-13, April-June.

Islam, R. \& Ahmed, S. (2014). Do managers and employees perceive motivating factors differently in Malaysia? International Journal of Business and System Research, 8(1), 72-90.

Ivancevich, J.M. (2004). Human resource management. 9th Ed., New York: McGraw Hill.

Jacobsen, C.B., Hvitved, J., \& Andersen, L.B. (2013). Command and motivation: How the perception of external interventions relates to intrinsic motivation and public service motivation. Public Administration, 1-17. DOI:10.1111/padm.12024 (Accessed 2014/04/25).

João, G., Calheiros, M.M., \& Barata, M.C. (2013). Authority in the classroom: adolescent autonomy, autonomy support, and teacher's legitimacy. European Journal of Psychology of Education, 28, 1065-1076.

Kagioglou, M., Cooper, R., \& Aouad, G. (2001). Performance management in construction: A conceptual framework. Construction Management and Economics, 19, 85-95.

Karami, A., Dolatabadi, H.R., \& Rajaeepour, S. (2013). Analysing the effectiveness of reward management system on employee performance through the mediating role of employee motivation case study: Isfahan Regional Electric Company. International Journal of Academic Research in Business and Social Sciences, 3(9), 327-338.

Katou, A.A. \& Budhwar, P. S. (2006). Human resource management systems and organisational performance is a test of mediating model in the Greek manufacturing context. International Journal of Human Resource Management, 17(7), 1223 - 1253.

Kelly, P. (2009). International business and management, London: South-Western, Cengage Learning, EMEA.

Khan, W. \& Mufti, O. (2012). Effect of compensation on motivating employees in public and private banks of Peshawar (BOK and UBL). Journal of Basic and Applied Scientific Research, 2(5), 4616-4623.

Kim, J.Y., Shim, J.P., \& Ahn, K.M. (2011). Social networking service: Motivation, pleasure, and behaviour intention to use. Journal of Computer Information System, Summer, 92-101.

Kohlbacher, M. \& Gruenwald, S. (2011). Process ownership, process performance management and firm performance. International Journal of Productivity and Performance Management, 60(7), 709-720.

Kulkarni, M. (2011). Revisiting Maslow the "IT" way: a case study. International Conference on Management (ICM 2011) proceedings, 48-57.

Lee, M.K.O., Cheung, C.M.K., \& Chen, Z. (2005). Acceptance of internet-based learning medium: The role of extrinsic and intrinsic motivation. Journal of Information and Management, 42(8), 1095-1104.

Lin, H.F. (2007). Effects of extrinsic and intrinsic motivation on employee knowledge sharing intentions. Journal of Information Science, 33(2), 135-149.

Malik, N. (2010). A study on motivational factors of the faculty members at University of Balochistan. Serbian Journal of Management, 5(1), 143-149.

Marinak, B.A. \& Gambrell, L.B. (2008). Intrinsic motivation and rewards: What sustains young children's engagement with text? Literacy Research and Instruction, 47(1), 9-26.

Martocchio, J.J. (2004). Strategic compensation: A human resource management approach, $3^{\text {rd }}$ ed., Upper Saddle River, New Jersey: Pearson, Prentice Hall.

Martocchio, J.J. (2006). Strategic compensation: A human resource management approach, $4^{\text {rd }}$ ed., Upper Saddle River, New Jersey: Pearson, Prentice Hall.

Mathis, R.L. \& Jackson, J.H. (2011). Human resource management. 13 th ed., USA: South-Western Cengage Learning.

Mattson, M., Torbiöm, I., \& Hellgren, J. (2014). Effects of staff bonus systems on safety behaviours. Human Resource Management Review, 24(1), 17-30.

Mawoli, M.A. \& Babandako, A.Y. (2011). An evaluation of staff motivation, dissatisfaction and job performance in an academic setting. Australian Journal of Business and Management Research, 1(9), 01-13.

McNall, L.A., Masuda, A.D., \& Nicklin, J.M. (2010). Flexible work arrangements, job satisfaction, and turnover intentions: The mediating role of work-to-family enrichment. The Journal of Psychology, 144(1), 61-81.

Milkovich, G.T. \& Newman, J.M. (1999). Compensation. $6^{\text {th }}$ Ed., New York: McGraw Hill.

Milkovich, G.T., Newman, J.M., and Gerhart, B. (2011). Compensation. 10th International Ed., New York: McGraw Hill.

Mucinsky, P.M., Kriek, H.J., \& Schreuder, A.M.G. (1998). Personnel psychology. Goodwood: Thomson Publishing Company.

Mumm, J. \& Mutlu, B. (2011). Designing motivational agents: the role of praise, social comparison, and embodiment in computer feedback. Computers in Human Behaviour, 27(5), 1643-1650.

Musenze, I.A, Thomas, M., Stella, B., \& Muhammadi, L. (2013). Reward management and organisational performance: An empirical study of private universities in Uganda. International Journal of Innovative Research and Development, 2(8), 90-96.

Nelson, B. \& Economy, P. (2005). The management bible. New Jersey: John Wiley and Sons Incorporation. 
Nickels, W.G., McHugh, J.M., \& McHugh, S.M. 1999. Understanding business. $5^{\text {th }}$ Ed. McGraw Hill Irwin, New York.

O'Connor, D. \& Yballe, L. (2007). Maslow revisited constructing a road map of human nature. Journal of Management Education, 31(6), 738-756.

Odunlade, R.O. (2012). Managing employee compensation and benefits for job satisfaction in libraries and information centres in Nigeria.

http://digitalcommons.unl.edu?utm_source=digitalcommons.unl.edu\%2flibphilprac\%2f714\&utmmedium=pdf\&utm_campaign=pdfc overpages/ (Accessed 2013:09:23).

Odusami, K.T., lyagba, R.R.O., \& Omirin, M.M. (2003). The relationship between project leadership, team composition and construction project performance in Nigeria. International Journal of Project Management, 21(7), 519-52.

Pingle, S. (2014). Reward and recognition practices in public sector: An empirical study at Steel Authority of India Ltd (SAIL). Journal of Institute of Environment and Management, 7(1), 10-15.

Prebensen, N.K., Woo, E., Chen, J.S., \& Uysal, M. (2012). Motivation and involvement as antecedent of the perceived value of the destination experience. Journal of Travel Research, 52(2), 253-264.

Qureshi, M. (2013). Relationship between rewards and employee motivation in Administration Block of Punjab University. International Journal of Innovative and Applied Finance, 1-13.

Riddell, C. (2011). Compensation policy and quit rates: A multilevel approach using benchmaking data. Industrial Relations: A Journal of Economy and Society, 50(4), 656-677.

Robbins, S.P. (2005). Organisational behaviour. International Ed., $11^{\text {th }}$ Ed., Pearson Education Incorporation, Upper Saddle River, New Jersey, USA.

Robbins, S.P. \& DeCenzo, D.A. (2008). Fundamentals of management: Essential Concepts and Applications, 6th ed., Pearson Educational Incorporation, Upper Saddle River, New Jersey, USA.

Schermerhorn, J.R.; Hunt, J.G., \& Osborn, R.N. (2008). Organisational behaviour, 10th Ed., John Wiley and Sons Incorporation, USA.

Seiler, S.; Lent, B.; Pinkowska, M., \& Pinazza, M. (2011). An integrated model of factors influencing project managers' motivationfindings from a Swiss survey. International Journal of Project Management, doi: 10.1016/j.ijproman.2011.03.002.

Shaw, J.D. (2014). Pay dispersion. The Annual Review of Organisational Psychology and Organisational Behaviour, 2014(1), 521-544.

Shieh, C.J. (2008). Effect of corporate compensation design on organisational performance. Social Behaviour and Personality, 36(6), 827-840.

Sisson, K. (2010). Employment relations matters. Research Studies and Reports, ILR collection. http://digitalcommons.ilr.cornell. edu/reports (Accessed 2014/ 04/17).

Stringer, C., Didham, J., \& Theivananthampillai, P. (2011). Motivation, pay satisfaction, and job satisfaction of front-line employees. Qualitative Research in Accounting and Management, 8(2), 161-179.

Tabassi, A.A. \& Abu Bakar, A.H. (2009). Training, motivation and performance: The case of human resource management in construction projects in Mashhad, Iran. International Journal of Project Management, 27(5), 471-480.

Todorović, M. \& Živković, S. (2010). Organisational culture in the function of occupational healthcare at work. 13th International Conference Dependability and Quality Management. ICDQM-2010, 155-161.

Tsai, C. (2005). Reward Incentive Compensation and Organisational Performance. Evidence from semi-conductor industry. Performance and Reward Conference, Manchester U.K.

Ude, U. \& Coker, M.A. (2012). Incentive schemes, employee motivation and productivity in organisations in Nigeria: Analytical linkages. Journal of Business and Management, 1(4), 32-39.

Ukandu, N.E. \& Ukpere, W.I. (2011). Strategies to improve the level of employee motivation in the fast food outlets in Cape Town, South Africa. Africa Journal of Business Management, 5(28), 11521-11531.

Van den Broeck, A., Schreurs, B., De Witte, H., Vansteenkiste, M., Germeys, F., \& Schaufeli, W. (2011). Understanding workaholics' motivations: A self-determination perspective. Applied Psychology: An International Review, 60(4), 600-621.

Vukšić, V.B., Bach, M.P., \& Popovič, A. (2013). Supporting performance management wiyh business process management and business intelligence: A case analysis of integration and orchestration. International Journal of Information Management, 33(4), 613-619.

Walker, C.O., Greene, B.A., \& Mansell, R.A. (2006). Identification with academics, intrinsic/extrinsic motivation, and self-efficacy as predictors of cognitive engagement. Learning and Individual Differences, 16(1), 1-12.

Willis-Shattuck, M., Bidwell, P., Thomas, S., Wyness, L., Blaauw, D., \& Ditlopo, P. (2008). Motivation and retention of health workers in developing countries: a systemic review. BMC Health Service Research, 8, 247. http://www.biomedcentral.com/1472-6963/8/247.

Wininger, S.R. \& Norman, A.D. (2010). Assessing coverage of Maslow's theory in educational psychology textbooks: a content analysis. Teaching Educational Psychology, 6(1), 33-48.

WorldatWork, (2007). The WorldatWork Handbook of Compensation, Benefits and Total Rewards: A comprehensive guide for HR professionals. John Wiley and Sonc, incorporation, New Jersey.

Xavier, B. (2014). Shaping the future research agenda for compensation and benefits management: Some thoughts based on stakeholder inquiry. Human Resource Management Review, 24(2014), 31-40. http://dox.doi.org/10.1016/j.hrmr.2013.08.011

Žicković, S. (2010). Contemporary concept of quality management in living and working environment safety. $6^{\text {th }}$ International Conference: Innovation-2010, Illyanovsk State University, Collection of Scientific Works, pp. 35-39.

Žicković, S. (2013). Management of occupational safety by motivating employees to work safely. African Journal of Business Management, 7(12), 936-946. 